\title{
POLA BAGI HASIL USAHA GARAM RAKYAT DI KABUPATEN PAMEKASAN, JAWA TIMUR
}

\author{
Campina Illa Prihantini ${ }^{1}$, Yusman Syaukat ${ }^{2}$, dan Anna Fariyanti ${ }^{3}$ \\ 1)Mahasiswa Ilmu Ekonomi Pertanian, Sekolah Pascasarjana, Institut Pertanian Bogor \\ 2)Staf Pengajar Departemen Ekonomi Sumberdaya dan Lingkungan, Fakultas Ekonomi dan Manajemen, \\ Institut Pertanian Bogor \\ 3)Staf Pengajar Departemen Agribisnis, Fakultas Ekonomi dan Manajemen, Institut Pertanian Bogor \\ e-mail : 1)camps.world.smaga@gmail.com, 2)ysyaukat@gmail.com, 3)a_fariyanti@yahoo.com
}

\begin{abstract}
Sharecropping system is wellknown as a disincentive agricultural system (Marshall 1920). It has been a culture that is very difficult to be deleted in rural area. Almost 70,5\% of salt production business in Pamekasan regency applied this system, although it does not give more adventages to the sharecroppers. This study aimed to analyze the sharecropping system in salt production by estimating the profit taken by landlords and sharecroppers. Beside that, this study aimed to identify the factors affecting sharecropper's decission by using binery logistic regression. The results showed that the landlords and the sharecroppers have a significant difference in the mean of their profit. This result is significant for $a=5 \%$. Sharecropper's decission is affected significantly by the last education of sharecropper, number of sharecropper's family, and cost of fund. This study recommended the government, landlords, sharecroppers, middleman, and the stakeholder to cooparate and make a forum that can give a better welfare to the sharecroppers.
\end{abstract}

Keywords: sharecropping system, salt production business, logistic regression.

\section{PENDAHULUAN}

Indonesia merupakan salah satu negara kepulauan di dunia. Hal ini membuat Indonesia memiliki potensi yang luar biasa dan keunggulan komparatif untuk memproduksi garam. Kebutuhan garam nasional mengalami peningkatan dari tahun ke tahun. Kementerian Perdagangan dan Kementerian Kelautan dan Perikanan Republik Indonesia (2011) menyatakan bahwa bahwa alasan meningkatnya kebutuhan garam adalah (1) pertambahan jumlah penduduk, (2) bertambahnya jumlah industri, dan (3) luas lahan garam yang tidak berubah.

Produksi garam nasional mengalami peningkatan dari tahun 2009 hingga tahun 2013. Namun, pada tahun 2010, produksi garam dalam negeri mengalami penururunan yang drastis karena adanya anomali iklim yang dapat menyebabkan kegagalan pada usaha garam rakyat (KKP 2014). Oleh karena itu, petani enggan berproduksi karena akan mengakibatkan kerugian. Pemerintah kemudian mengambil kebijakan untuk memenuhi kebutuhan garam nasional yakni dengan memberikan subsidi input kepada petani garam dan stakeholder terkait dalam program Pemberdayaan Usaha Garam Rakyat (PUGAR). Program ini ternyata memberikan dampak yang signifikan karena pada tahun 2011 dan 2012 Indonesia mampu berswasembada garam konsumsi (KKP 2014, Jamil 2014).

Provinsi Jawa Timur merupakan lumbung garam nasional yang memberikan kontribusi sebesar 47 persen terhadap produksi garam nasional (BPS 2014). Keberadaan Pulau Madura sangat memengaruhi produksi garam Provinsi Jawa Timur. Hampir 95 persen lahan garam Provinsi Jawa Timur berada di Pulau Madura (KKP 2010). Pulau Madura memiliki empat kabupaten sebagai produsen garam terbesar di Indonesia, salah satunya adalah Kabupaten Pamekasan.

Kabupaten Pamekasan tercacat sebagai kabupaten produsen garam terbesar ketiga di Provinsi Jawa Timur dimana masih terdapat sekitar 31 persen lahan garam yang belum dimanfaatkan secara optimal (KKP 2010). Kabupaten Pamekasan memiliki potensi yang 
memadai untuk dilakukan pengembangan usaha garam rakyat. Jamil (2014) dan Prihantini (2015) menyebutkan bahwa produktivitas di Kabupaten Pamekasan cukup tinggi. Namun, keuntungan yang diterima oleh petani garam masih rendah sehingga kesejahteraan petani pun masih rendah. Penyebab utama masih rendahnya keuntungan yang diterima oleh petani garam adalah masih banyaknya usaha garam yang dijalankan sebagai usaha bagi hasil. Dalam laporan yang disampaikan oleh Bupati Pamekasan, terdapat sekitar 70,5 persen petani garam di Kabupaten Pamekasan menerapkan sistem bagi hasil atau dikenal dengan istilah mantong (SEKDAKAB Pamekasan 2016). Sistem bagi hasil membuat pemilik lahan atau pemodal menjadi dominan dalam hal pemasaran dan permodalan (Sukesi 2011). Hal inilah yang membuat sistem bagi hasil kurang memberikan keadilan kepada petani penggarap.

Sistem bagi hasil merupakan sistem pertanian yang disincentive. Hal ini dibuktikan oleh Marshall (1920) dengan adanya penyebutan istilah sleeping dan working partner dalam bukunya menyebutkan sebagai berikut:

'The ownership of land is vested, not in an individual, but in a firm of which one member or group of members is the sleeping partner, while another member or goup of members (it may be awhole family) is the working partner'.

Sistem bagi hasil ini telah menjadi budaya yang sangat sulit untuk dihilangkan dari kehidupan masyarakat pedesaan. Kajian mengenai bagi hasil telah banyak dilakukan. Salah satu permasalahan utama mengapa bagi hasil belum memberikan keadilan kepada petani penggarap dalam usaha garam di Kabupaten Pamekasan adalah adanya perbedaan tujuan yang ingin dicapai oleh pemilik lahan dan petani penggarap (Debertin 1986).

Di sisi lain, sistem bagi hasil sangat sulit dihilangkan karena adanya pandangan bahwa bagi hasil adalah budaya dan warisan yang telah ada dan berkembang secara turuntemurun (Scheltema 1985). Aspek sosial, budaya, dan ekonomi masyarakat pedesaan bahkan memandang bagi hasil sebagai solusi permasalahan pertanian dan perekonomian, seperti (1) peningkatan penerimaan petani penggarap, (2) penyerapan excess supply tenaga kerja, (3) keterbatasan modal, dan (4) keterbatasan lahan (Lole 1995). Adanya pandangan seperti itu semakin membuat petani penggarap bergantung pada pemilik lahan dan hal-hal yang kurang menguntungkan petani penggarap dipandang sebagai sebuah kewajaran.

Penjelasan dan latar belakang di atas menghasilkan dua tujuan penelitian, yakni :

1. Mengestimasi tingkat keuntungan yang diterima oleh masing-masing pihak antar pola usaha garam rakyat di Kabupaten Pamekasan.

2. Mengidentifikasi faktor-faktor yang memengaruhi partispasi petani penggarap terhadap pola bagi hasil tertentu dalam usaha garam rakyat di Kabupaten Pamekasan.

Penelitian ini hanya membahas bagaimana tingkat keuntungan yang diterima oleh masing-masing pihak yang terlibat dalam sistem bagi hasil usaha garam rakyat di Kabupaten Pamekasan. Salah satu keterbatasan penelitian ini adalah belum dikaji lebih lanjut mengenai aspek-aspek dalam sistem bagi hasil, seperti (a) pengendalian risiko, (b) efek penyeleksian anggota, (c) moral hazard, dan (d) keterbatasan modal. Oleh karena itu, diperlukan kajian lebih lanjut mengenai aspek-aspek dalam sistem bagi hasil, seperti (a) kepastian pasar, (b) kepastian input, (c) penanganan biaya transaksi, (d) pengendalian resiko, (f) moral hazard, dan (g) keterbatasan modal atau pembiayaan.

\section{KERANGKA PEMIKIRAN}

\section{KONSEP USAHATANI}

Keuntungan suatu usahatani dipengaruhi oleh struktur penerimaan dan struktur biaya. Sehingga fungsi keuntungan yang 
Tabel 1. Matriks Struktur Bagi Hasil dengan Bagi Biaya

\begin{tabular}{|l|c|c|}
\hline \multicolumn{1}{|c|}{ Struktur } & Pemilik Lahan & Petani Penggarap \\
\hline Biaya (TC) & $1-\mathrm{h}$ & $\mathrm{h}$ \\
\hline $\begin{array}{l}\text { Penerimaan (TR) } \\
\text { FOC }\end{array}$ & $1-\mathrm{k}$ & $\mathrm{k}$ \\
\hline
\end{tabular}

Sumber : Debertin (1986)

diperoleh dalam suatu usahatani memenuhi persamaan berikut:

$$
\begin{aligned}
& \mathrm{TR}=\sum \text { Pyi } . \mathrm{Yi} \\
& \mathrm{TC}=\mathrm{TFC}+\mathrm{TVC} \\
& \Pi=\mathrm{TR}-\mathrm{TC}
\end{aligned}
$$

Suatu usahatani dapat dikatakan mencapai kondisi yang memaksimumkan keuntungan jika fisrt order condition (FOC) dan second order condition (SOC)-nya terpenuhi (Debertin 1986). Sehingga, fungsi FOC dari fungsi keuntungan di atas adalah :

$$
\begin{aligned}
& \mathrm{d} \Pi / \mathrm{dy}=0 \\
& \mathrm{MR}=\mathrm{MC}
\end{aligned}
$$

Sedangkan untuk kondisi SOC-nya, suatu usahatani dikatakan telah mencapai keuntungan yang maksimum jika :

$$
\frac{d M R}{d y}-\frac{d M C}{d y}<0
$$

Dimana :

$$
\begin{aligned}
\mathrm{TR}= & \text { Besar penerimaan (total revenue) dalam } \\
& \text { usahatani (Rupiah) } \\
\mathrm{TC}= & \text { Total biaya yang dikeluarkan (total } \\
& \text { cost) dalam usahatani (Rupiah) } \\
\mathrm{TFC}= & \text { Total biaya tetap yang dikeluarkan } \\
& \text { (total fixed cost) dalam usahatani } \\
& \text { (Rupiah) } \\
\mathrm{TVC}= & \text { Total biaya input variabel yang } \\
& \text { dikeluarkan dalam usahatani (total } \\
& \text { variable cost) (Rupiah) } \\
\mathrm{MC}= & \text { Biaya marjinal (marginal cost) } \\
\mathrm{MR}= & \text { Penerimaan marjinal (marginal revenue) } \\
\mathrm{Py}= & \text { Harga output dari komuditi ke-i } \\
& \text { (Rupiah per unit) } \\
\mathrm{Y}_{\mathrm{i}}= & \text { Output produksi komuditi ke-i (unit } \\
& \text { atau ton) } \\
\Pi= & \text { Besar keuntungan yang diterima dari } \\
& \text { usahatani (Rupiah) }
\end{aligned}
$$

\section{TEORI BAGI HASIL}

Sistem bagi hasil dapat dibedakan menjadi dua tipe, yakni (a) bagi hasil dengan tanpa bagi biaya dan (b) bagi hasil dengan bagi biaya. Perbedaan keduanya hanya terletak pada ada tidaknya pembagian biaya. Besaran pembagian biaya tersebut disepakati antara pemilik lahan dan petani penggarap. Usaha garam rakyat yang dijalankan di Kabupaten Pamekasan ternyata menggunakan sistem bagi haisl dengan bagi biaya, sehingga teori yang akan dibahas adalah mengenai bagi haisl dengan bagi biaya. Masing-masing pihak menerima bagian yang telah disepakati bersama, baik bagian dari penerimaan maupun bagian dari biaya yang harus ditanggungnya. Setelah dilakukan analisis The Equimarginal Return (dengan melakukan analisis FOC), diperoleh hasil seperti yang tertera dalam Tabel 1 .

Dari Tabel 1 dapat disimpulkan bahwa jika bagian bagi biaya lebih besar dari bagian bagi hasil (h > k), maka VMP (Value Marginal Product) lebih kecil daripada MFC (Marginal Factor Cost) . Pun demikian jika $\mathrm{h}<\mathrm{k}$, maka VMP lebih besar daripada MFC. Seperti yang telah disebutkan sebelumnya, mengenai konsep The Equimarginal Return, dimana untuk memberikan kondisi yang optimal bagi kedua pihak adalah ketika VMP = MFC dan itu tercapai ketika $h=k$ (Debertin 1986). Dengan demikian, jelas bahwa nilai $\mathrm{h}$ dan $\mathrm{k}$ adalah faktor penentu dalam bagi hasil bagi kedua belah pihak.

\section{METODE PENELITIAN}

Penelitian ini dilakukan di tiga kecamatan di Kabupaten Pamekasan, yakni Kecamatan Tlanakan, Kecamatan Galis, dan Kecamatan Pademawu yang tercatat sebagai tiga produsen garam terbesar di Kabupaten Pamekasan selama bulan Maret hingga April 2016. 
Jenis data yang digunakan dalam penelitian ini adalah data primer dan data sekunder. Data primer diperoleh dengan menyebarkan kuesioner dan melakukan wawancara langsung kepada responden. Responden yang digunakan adalah pemilik lahan dan petani penggarap di tiga kecamatan di Kabupaten Pamekasan. Data sekunder diperoleh dari dinas, kementerian terkait, dan sumber lainnya yang relevan dengan penelitian ini.

Penentuan responden menggunakan metode purposive dan snowballing sampling. Jumlah responden yang akan digunakan dalam penelitian ini adalah sebanyak 115 orang. Metode analisis yang digunakan dalam penelitian ini mencakup analisis kualitatif dan analisis kuantitatif. Analisis kualitatif dan kuantitatif dijelaskan secara deskriptif, seperti analisis keuntungan dalam pola bagi hasil dan analisis regresi logistik untuk mengetahui faktor-faktor yang memengaruhi keputusan petani penggarap terhadap pola bagi hasil. Pengolahan analisis kuantitatif dilakukan dengan menggunakan program Microsoft Excel 20013 dan Minitab 11.

\section{ANALISIS KEUNTUNGAN DALAM POLA BAGI HASIL}

Analisis ini digunakan untuk melihat keuntungan yang diterima oleh pemilik lahan dan petani penggarap Secara matematis, keuntungan yang diperoleh oleh petani penggarap dan pemilik lahan memenuhi persamaan berikut.

$$
\begin{aligned}
\Pi \mathrm{F}= & (\mathrm{k})^{*}\left[\left(\mathrm{P}_{1} . \mathrm{Y}_{1}\right)+\left(\mathrm{P}_{2} . \mathrm{Y}_{2}\right)+\left(\mathrm{P}_{3} . \mathrm{Y}_{3}\right)\right]- \\
& (\mathrm{k})^{*}(\mathrm{TVC}) \\
\Pi L= & \left(1-\mathrm{k}^{*}\left[\left(\mathrm{P}_{1} . \mathrm{Y}_{1}\right)+\left(\mathrm{P}_{2} . \mathrm{Y}_{2}\right)+\left(\mathrm{P}_{3} . \mathrm{Y}_{3}\right)\right]-\right. \\
& (1-\mathrm{k})^{*}(\mathrm{TFC})-(1-\mathrm{k})^{*}(\mathrm{TVC})+(1- \\
& \mathrm{k})^{*}\left(\mathrm{COF} \mathrm{CORDT}^{*}\right) \\
\frac{\pi \mathrm{F}}{\pi \mathrm{L}}= & \mu
\end{aligned}
$$

Dimana :

$\Pi \mathrm{F} \quad=$ Keuntungan yang diterima oleh petani penggarap $(\mathrm{Rp})$

$\Pi \mathrm{L} \quad=$ Keuntungan yang diterima oleh pemilik lahan $(\mathrm{Rp})$ $\mathrm{k}=$ Koefisien besarnya bagi hasil, $\mathrm{k}=\frac{1}{2}$ dan $\mathrm{k}=\frac{1}{3}$

$\mathrm{P}_{\mathrm{i}} \quad=$ Harga garam Kualitas Produksi (KP) ke-i (Rp per ton)

$\mathrm{Y}_{\mathrm{i}} \quad=$ Jumlah garam Kualitas Produksi (KP) ke-i (ton)

TVC = Total variable cost atau besarnya biaya total variabel (Rp)

TFC = Total fixed cost atau besarnya biaya total tetap $(\mathrm{Rp})$

$\mathrm{COF}=$ Besarnya biaya pinjaman (persen)

KRDT = Besarnya pinjaman (kredit) yang diberikan (Rp)

$\mu \quad=$ Nilai perbandingan keuntungan relatif

Nilai $\mu$ yang diharapkan adalah $0<\mu<1$. Suatu pola bagi hasil dikatakan semakin berkeadilan jika nilai $\mu$ mendekati angka 1 . Pun sebaliknya, suatu pola bagi hasil dikatakan semakin tidak memberikan keadilan jika nilai $\mu$ semakin mendekati angka 0 .

\section{FAKTOR-FAKTOR YANG MEMENGARUHI KEPUTUSAN PETANI PENGGARAP TERHADAP POLA BAGI HASIL}

Analisis ini digunakan untuk mengetahui faktor-faktor yang memengaruhi keputusan petani penggarap dalam berpartisipasi terhadap suatu pola bagi hasil. Analisis ini dapat dilakukan dengan menggunakan metode regresi logistik (Gujarati 2003). Sehingga persamaan model logistik yang diperoleh adalah :

$$
\begin{aligned}
\mathrm{L}_{\mathrm{i}}= & \ln \left(\frac{p i}{1-p i}\right)=\mathrm{Z}_{\mathrm{i}}=\alpha_{0}+\alpha_{1} \mathrm{X}_{1}+\alpha_{2} \mathrm{X}_{2}+ \\
& \alpha_{3} \mathrm{X}_{3}+\alpha_{4} \mathrm{X}_{4}+\alpha_{5} \mathrm{X}_{5}+\alpha_{6} \mathrm{X}_{6}+\alpha_{7} \mathrm{X}_{7}
\end{aligned}
$$

Dimana :

$\mathrm{L}_{\mathrm{i}} \quad=$ Persamaan logistik

$\mathrm{P}_{\mathrm{i}} \quad=$ Peluang individu dalam mengambil keputusan berpartisipasi dalam pola bagi dua

$\left(1-\mathrm{P}_{\mathrm{i}}\right)=$ Peluang individu dalam mengambil keputusan berpartisipasi dalam pola bagi tiga

$\mathrm{Z}_{\mathrm{i}} \quad=$ Keputusan petani penggarap

$\mathrm{a}_{0} \quad=$ Intersep

$\mathrm{a}_{\mathrm{i}} \quad=$ Parameter peubah $X_{\mathrm{i}}$

$\mathrm{X}_{1} \quad=$ Usia petani penggarap (tahun) 


$$
\begin{array}{rlr}
X_{2}= & \text { Pengalaman bertani petani } \\
& \text { penggarap (tahun) } & \\
X_{3}= & \text { Pendidikan terakhir petani } \\
& \text { penggarap } \\
X_{4} & = & \text { Jumlah anggota keluarga } \\
& \text { penggarap (orang) } \\
X_{5}= & \text { Jarak gudang ke jalan raya (meter) } \\
X_{6}= & \text { Biaya pinjaman yang dibayar petani } \\
& \text { penggarap (peresen) } \\
X_{7}= & \text { Proporsi garam Kualitas Produksi } \\
& \text { (KP) } 1 \text { (persen) }
\end{array}
$$

\section{KARAKTERISTIK POLA BAGI HASIL DAN RESPONDEN USAHA GARAM RAKYAT}

Pola bagi hasil usaha garam rakyat yang umum dilaksanakan di Kabupaten Pamekasan adalah pola bagi dua dan pola bagi tiga. Hal ini telah sesuai dengan hasil penelitian Negara (2003) bahwa pola bagi hasil yang sering diterpakan dalam sektor pertanian adalah pola bagi dua dan pola bagi tiga. Kedua pola ini memiliki karakteristik yang tidak jauh berbeda. Terdapat beberapa hal yang sekiranya menjadi pembeda antara pola bagi dua dan pola bagi tiga.

\section{POLA BAGI DUA}

Pola bagi dua merupakan pola bagi hasil yang sebenarnya khusus dilakukan jika lahan garam yang akan diusahakan masih bersifat baru atau mudah mengalami kebocoran (dikenal dengan istilah rembes). Pola ini memberikan bagian yang sama besar antara pemilik lahan dan petani penggarap. Artinya, pemilik lahan dan petani penggarap maisngmasing menerima satu bagian. Lahan garam yang baru atau mudah bocor membutuhkan perlakuan yang istimewa. Perlakuan yang dimaksud adalah membutuhkan perawatan yang ekstra, sehingga petani penggarap berkewajiban untuk menanggung biaya tambahan perbaikan lahan garam.

Biaya tambahan perbaikan lahan yang bocor pada umumnya cukup besar. Hal ini sebanding dengan bagian yang diterima oleh petani penggarap, dimana lebih besar daripada bagian yang diterima oleh petani penggarap pola bagi tiga. Oleh karena itu, insentif yang diterima oleh petani penggarap poa bagi dua sebenarnya adalah subsidi silang untuk menutupi biaya tambahan perbaikan lahan. Kondisi lahan garam yang mulai membaik akan mengembalikan pola bagi dua menjadi pola bagi tiga. Artinya, petani penggarap pola bagi dua akan berubah pola bagi hasilnya menjadi pola bagi tiga jika kondisi lahan garam telah baik. Kesimpulan yang dapat diambil adalah pemilik lahan tidak ingin dirugikan dengan kondisi lahan yang buruk dengan menerapkan pola bagi dua. Inilah salah satu bukti ketidakadilan dalam pola bagi hasil usaha garam rakyat.

\section{POLA BAGI TIGA}

Pola bagi tiga merupakan pola bagi hasil yang sangat umum dilakukan di Kabupaten Pamekasan. Pemilik lahan menerima satu bagian dan petani penggarap hanya menerima satu bagian saja. Lahan yang dikerjakan oleh petani penggarap biasanya merupakan lahan yang kondisinya baik untuk berproduksi garam. Kondisi lahan garam yang baik membuat pemilik lahan memprediksikan produksi garam yang tinggi. Sehingga bagian yang diterima oleh pemilik lahan lebih besar daripada petani penggarap.

Selain itu, petani penggarap pada pola bagi tiga tidak perlu menanggung biaya tambahan perbaikan lahan, sehingga biaya yang ditanggung oleh petani penggarap pola bagi tiga relatif lebih rendah daripada petani penggarap pola bagi dua. Kesimpulan yang dapat diambil adalah baik pola bagi dua maupun pola bagi tiga ternyata kurang memberikan keadilan kepada petani penggarap. Salah satu indikator ketidakdilan adalah keuntungan yeng diterima oleh petani penggarap lebih kecil daripada keuntungan yang diterima oleh pemilik lahan (Tabel 1). Hal ini akan dijelaskan pada bab berikutnya.

\section{PERBANDINGAN JUMLAH RESPONDEN}

Jumlah responden yang digunakan dalam penelitian ini adalah sejumlah 115 orang. Jumlah pemilik lahan adalah 22 orang 
atau sekitar 19,13 persen dan petani penggarap sejumlah 93 orang atau 80,87 persen. Petani penggarap yang tergabung dalam pola bagi dua sejumlah 13 orang atau 13,98 persen dan sisanya, yakni 80 orang atau 86,02 persen adalah petani penggarap yang tergabung dalam pola bagi tiga. Kesimpulan yang dapat diambil adalah setiap pemilik lahan dapat bekerjasama dengan 4 hingga 5 orang petani penggarap. Artinya, jumlah petani penggarap tersebut sangat memungkinkan terjadinya dominasi dan monopoli oleh pemilik lahan. Hal ini telah sesuai dengan hasil penelitian yang dilakukan oleh Ray (1999) dan Roy et al. (2001).

\section{USIA RESPONDEN}

Usia responden berada dalam rentang 21 hingga 87 tahun. Rata-rata usia responden adalah 41 tahun. Sejumlah sembilan orang atau sekitar 7,8 persen responden berada dalam kategori umur <15 tahun atau >60 tahun. Responden yang berada dalam kategori usia 51 hingga 60 tahun adalah sejumlah sepuluh orang atau sebesar 8,7 persen. Responden yang berada dalam kategori umur 15 hingga 50 tahun sejumlah 96 orang atau mencapai 83,5 persen. Kesimpulan yang dapat diambil adalah responden yang digunakan berada dalam kategori usia produktif, yakni kisaran usia 15 hingga 50 tahun. Hal ini dapat dilihat dari ptouktivitas lahan garam yang dapat mencapai angka 120 ton per hektar.

\section{TINGKAT PENDIDIKAN TERAKHIR}

Responden yang memiliki tingkat pendidikan terakhir tingkat Sekolah Dasar sejumlah 61 orang atau mencapai 53,04 persen. Responden yang tidak menuntaskan sekolah sejumlah 28 orang atau 24,35 persen. Responden yang tingkat pendidikan terkahir minimal Sekolah Menengah Pertama atau hingga Sarjana sejumlah 26 orang atau hanya sekitar 22,61 persen saja. Kesimpulan yang dapat diambil bahwa responden masih memiliki pendidikan yang relatif rendah. Hal ini sangat disayangkan karena pendidikan akan berpengaruh terhadap kemampuan menerima informasi, teknologi, dan pengambilan keputusan. Namun, seiring dengan pengalaman bertani, pendidikan ini dapat didukung dengan pengalaman bertani yang dimiliki.

\section{PENGALAMAN BERTANI}

Pengalaman bertani memengaruhi skill dan perilaku dalam membuat keputusan usaha garam yang dijalankan. Responden yang memiliki pengalaman bertani tidak lebih dari lima tahun ( $<5$ tahun) berjumlah tujuh orang atau hanya sekitar 6,08 persen saja. Responden yang memiliki pengalaman bertani kisaran lima hingga lima belas tahun berjumlah 34 orang atau sekitar 29,57 persen. Responden yang memiliki pengalaman bertani lebih dari lima belas tahun ( $>15$ tahun berjumlah 74 orang atau mencapai 64,35 persen. Kesimpulan yang dapat diambil bahwa pada umumnya responden memiliki pengalaman bertani yang relatif lama. Hal ini memengaruhi pada skill dalam memroduksi garam dan perilaku pengambilan keputusan usaha garam.

\section{ANALISIS KEUNTUNGAN YANG DITERIMA DALAM POLA BAGI HASIL USAHA GARAM RAKYAT}

Tingkat keuntungan yang diterima oleh petani penggarap dan pemilik lahan untuk setiap pola bagi hasil ternyata berbeda. Berdasarkan hasil perhitungan dan analisis di lapangan, dapat disimpulkan bahwa terdapat perbedaan keuntungan yang nyata antara petani penggarap dan pemilik lahan untuk setiap pola bagi hasil. Berdasarkan Tabel 2, untuk pola bagi dua, tingkat keuntungan yang diterima oleh petani penggarap berada dalam kisaran Rp 4,9 juta hingga Rp 19,5 juta dengan rata-rata tingkat keuntungan sebesar Rp 12,8 juta (per hektar per musim). Tingkat keuntungan yang diterima oleh pemilik lahan berada dalam kisaran Rp 150,9 juta hingga Rp 764,5 juta dengan rata-rata tingkat 
keuntungan sebesar Rp 480,8 juta (per hektar per musim). Berdasarkan hasil analisis uji beda (Two Sample T-Test and Confidence Interval) dalam Lampiran 1, perbedaan ratarata keuntungan yang diterima petani penggarap dan pemilik lahan pada pola bagi dua ini dinyatakan nyata pada taraf nyata lima persen.

Tingkat keuntungan yang diterima oleh petani penggarap pola bagi tiga yang disajikan dalam Tabel 2 berada dalam kisaran Rp 5,3 juta hingga Rp 46,1 juta dengan ratarata keuntungan sebesar Rp 13,2 juta (per hektar per musim). Sedangkan tingkat keuntungan yang diterima oleh pemilik lahan berada dalam kisaran Rp 103,6 juta hingga Rp 2,6 miliar dengan rata-rata sebesar Rp 686,9 juta (per hektar per musim). Uji beda (Two Sample T-Test and Confidence Interval) yang dilakukan pada pola bagi tiga ini menyimpulkan bahwa terdapat perbedaan rata-rata keuntungan yang nyata antara petani penggarap dan pemilik lahan dalam taraf nyata lima persen. Hal ini disampaikan dalam Lampiran 1.

Secara kesuluruhan, berdasarkan Tabel 2 , keuntungan yang diterima oleh petani penggarap untuk berbagai pola berada dalam kisaran Rp 4,9 juta hingga Rp 46,1 juta dengan rata-rata keuntungan sebesar Rp 13,1 juta (per hektar per musim). Sedangkan untuk pemilik lahan, keuntungan yang diterima berada dalam kisaran Rp 103,6 juta hingga Rp 2,6 miliar dengan rata-rata keuntungan sebesar Rp 658 juta (per hektar per musim). Perbedaan rata-rata keuntungan yang diterima oleh petani penggarap dan pemilik lahan untuk berbagai pola ini juga dinyatakan berbeda nyata dalam taraf nyata lima persen. Kesimpulan ini didasarkan pada hasil uji beda (Two Sample T-Test and Confidence Interval) dalam Lampiran 1.

Kesimpulan yang dapat diambil adalah keuntungan yang diterima oleh petani penggarap berbeda nyata terhadap keuntungan yang diterima oleh pemilik lahan. Hal ini disebabkan karena pemilik lahan memperoleh penerimaan yang cukup besar dari biaya pinjaman yang harus dibayar oleh petani penggarap. Kajian ini sama hasilnya dengan penelitian yang telah dilakukan oleh Basu (1997). Bahkan, berdasarkan hasil perhitungan, kontribusi penerimaan dari biaya pinjaman yang diterima oleh pemilik lahan terhadap keuntungan berada dalam range 85,29 hingga 98,69 persen. Artinya, keuntungan pemilik lahan cenderung berasal dari penerimaan biaya pinjaman. Inilah indikator lain dalam hal ketidakadilan bagi hasil terhadap petani penggarap. Hal ini telah sesuai dengan hasil kajian yang dilakukan oleh Nurdiani (2013).

\section{PERBANDINGAN NILAI KEUNTUNGAN RELATIF ANTAR POLA BAGI HASIL}

Nilai koefisien keuntungan relatif $(\mu)$ merupakan perbandingan keuntungan yang diterima oleh petani penggarap terhadap keuntungan yang diterima oleh pemilik lahan. Nilai $\mu$ yang diharapkan berada dalam rentang nilai $0<\mu<1$.

Tabel 2. Perbandingan Perdedaan Keuntungan yang Diterima untuk Setiap Pola Bagi Hasil

\begin{tabular}{|l|r|r|r|}
\hline \multicolumn{1}{|c|}{ Pola Bagi Hasil } & \multicolumn{2}{|c|}{ Keuntungan yang Diterima (Rp/Ha/Musim) } \\
\hline Pola Bagi Dua & Minimum & \multicolumn{1}{c|}{ Raksimum } & \multicolumn{1}{c|}{ Rata-rata } \\
\hline Pemilik Lahan & & & \\
\hline Petani Penggarap & 150.895 .350 & 764.513 .000 & $480.804 .887^{* *}$ \\
\hline Pola Bagi Tiga & 4.910 .075 & 19.492 .625 & $12.833 .733^{* *}$ \\
\hline Pemilik Lahan & & & \\
Petani Penggarap & 103.616 .400 & 2.628 .112 .267 & $686.851 .422^{* *}$ \\
\hline Antar Pola Bagi Hasil & 5.277 .033 & 46.122 .717 & $13.163 .211^{* *}$ \\
\hline Pemilik Lahan & & & \\
\hline Petani Penggarap & 103.616 .400 & 2.628 .112 .267 & $658.049 .219^{* *}$ \\
\hline
\end{tabular}

Sumber : Data Primer (2016)

Keterangan : ** $=$ nyata pada taraf $\mathrm{a}=5 \%$ 
Tujuan utama analisis ini adalah untuk melihat pola bagi hasil manakah yang paling memberikan keadilan kepada masing-masing pihak yang terlibat dalam pola bagi hasil tertentu. Jika nilai $\mu=0$ maka pola bagi hasil tersebut dikatakan tidak memberikan keadilan kepada petani penggarap dan pemilik lahan. Artinya, pola bagi hasil tersebut jauh dari kata adil. Sebaliknya, jika nilai $\mu=1$, maka pola bagi hasil tersebut memberikan keadilan kepada petani penggarap dan pemilik lahan. Artinya, keuntungan yang diperoleh oleh petani penggarap sama besarnya dengan keuntungan yang diterima oleh pemilik lahan.

Berdasarkan hasil analisis dan perhitungan dalam Tabel 2, nilai $\mu$ pada pola bagi dua berada dalam rentang nilai 0,013 hingga 0,072 dengan nilai rata-rata $\mu$ sebesar 0,030 . Nilai rata-rata $\mu=0,030$ dapat diartikan bahwa keuntungan yang diterima oleh petani penggarap hanya sebesar 3 persen dari keuntungan yang diterima oleh pemilik lahan. Nilai $\mu$ yang sangat rendah ini merupakan salah satu indikator bahwa pola bagi dua belum memberikan keadilan kepada petani penggarap. Hal ini dapat terjadi karena pemilik lahan menerima keuntungan yang sangat besar dari biaya pinjaman atas pinjaman yang diberikan kepada petani penggarap. Biaya pinjaman yang dibayarkan oleh petani penggarap kepada pemilik lahan ternyata memberikan dampak yang besar terhadap keuntungan yang diperoleh. Penerimaan dari biaya pinjaman diterima secara tidak langsung. Artinya, petani penggarap cenderung kurang paham mengenai hal tersebut.
Nilai $\mu$ untuk pola bagi tiga, dalam Tabel 3 , berada dalam rentang nilai 0,010 hingga 0,074 dengan nilai rata-rata $\mu$ sebesar 0,022 . Nilai rata-rata $\mu=0,022$ dapat diartikan bahwa keuntungan yang diterima oleh petani penggarap hanya sebesar 2,2 persen dari keuntungan yang diterima oleh pemilik lahan. Nilai $\mu$ yang juga mendekati nilai 0 tersebut mengindikasikan bahwa pola bagi tiga ternyata belum memberikan keadilan kepada petani penggarap. Hal ini dapat terjadi karena pemilik lahan menerima keuntungan dari biaya pinjaman yang tinggi atas pinjaman yang diberikan kepada petani penggarap.

Secara keseluruhan, nilai $\mu$ untuk berbagai pola berada dalam rentang nilai 0,010 hingga 0,074 dengan nilai rata-rata $\mu$ sebesar 0,023 . Nilai rata-rata $\mu=0,023$ menunjukkan bahwa keuntungan yang diterima oleh petani penggarap dalam berbagai pola hanya sebesar 2,3 persen dari keuntungan yang diterima oleh petani penggarap. Nilai rata-rata $\mu$ yang juga mendekati nilai 0 mengindikasikan bahwa baik pola bagi dua maupun pola bagi tiga tidak memberikan keadilan kepada petani penggarap. Nilai rata-rata $\mu$ pola bagi tiga ternyata lebih kecil daripada nilai rata-rata $\mu$ pola bagi dua. $\left(\mu_{3}<\mu_{2}\right)$. Artinya, pola bagi tiga lebih memberikan keadilan kepada petani penggarap daripada pola bagi tiga sebesar 0,7 persen saja. Namun, secara keseluruhan, kedua pola bagi hasil ini belum memberikan keadilan kepada petani penggarap. Artinya, masih terdapat dominasi pemilik lahan dalam pola bagi hasil usaha garam rakyat di Kabupaten Pamekasan (Ray 1999, Roy et al. 2001).

Tabel 3. Perbandingan Koefisien Keuntungan Relatif untuk Setiap Pola Bagi Hasil

\begin{tabular}{|l|r|r|r|}
\multicolumn{1}{|c|}{ Pola Bagi Hasil } & \multicolumn{3}{c|}{ Nilai $\mu$} \\
\hline Pola Bagi Dua & Minimum & Maksimum & \multicolumn{1}{c|}{ Rata-rata } \\
\hline Pola Bagi Tiga & 0,013 & 0,072 & 0,030 \\
\hline Antar Pola Bagi Hasil & 0,010 & 0,074 & 0,022 \\
\hline Sumber : Data Primer (2016) & 0,010 & 0,074 & 0,023 \\
\hline
\end{tabular}




\section{FAKTOR-FAKTOR YANG MEMENGARUHI KEPUTUSAN PETANI PENGGARAP TERHADAP POLA BAGI HASIL}

Analisis faktor-faktor yang memengaruhi keputusan petani penggarap terhadap suatu pola bagi hasil menggunakan analisis regresi logistik. Variabel independen yang digunakan dalam analisis ini adalah usia petani penggarap, pengalaman bertani dari petani penggarap, tingkat pendidikan terakhir petani penggarap, jumlah anggota keluarga dari petani penggarap, jarak gudang ke jalan raya, biaya pinjaman yang dibayar oleh petani penggarap, dan proporsi Kualitas Produksi (KP) 1. Hasil analisis regresi logistik disampaikan dalam Tabel 3 dan disajikan secara lengkap dalam Lampiran 2.

\section{UJI SIGINIFIKANSI MODEL (UJI G)}

Berdasarkan hasil uji G pada Tabel 4 diperoleh nilai $G$ sebesar 14,991 dan nilai $L o g$ Likelihood sebesar $-30,130 . \mathrm{H}_{0}=0$ = variabel independen tidak berpengaruh nyata terhadap variabel dependen. $\mathrm{H}_{1} \neq 0=$ variabel independen berpengaruh nyata terhadap variabel dependen. Nilai $P$-Value sebesar 0,036 $(P$-Value $<0,05)$ dapat disimpulkan bahwa tolak $\mathrm{H}_{0}$ artinya secara bersama-sama variabel independen berpengaruh nyata terhadap keputusan petani penggarap untuk berpartisipasi pada suatu pola bagi hasil.

\section{UJI KEBAIKAN MODEL (GOODNESS OF FIT TESTS)}

Hasil output dengan menggunakan program Minitab 11 dalam Tabel 4 menunjukkan uji kebaikan model (goodness of fit tests) yang dilihat dari nilai P-Value dari setiap metode yang digunakan, yakni Pearson, Deviance, dan Hosmer-Lemeshow Tests. $\mathrm{H}_{0}$ : Model telah cukup mampu menjelaskan data. $\mathrm{H}_{1}$ : Model tidak cukup mampu menjelaskan data. $\mathrm{H}_{1}$ : Model tidak cukup mampu menjelaskan data. Nilai $P$-Value bernilai lebih besar dari taraf nyata lima persen, sehingga dapat disimpulkan tolak $\mathrm{H}_{0}$ yang artinya model ini cukup mampu menjelaskan data atau model ini layak untuk digunakan.

Tabel 4. Hasil Analisis Regresi Faktor-Faktor yang Memengaruhi Keputusan Petani Penggarap Terhadap Pola Bagi Hasil

\begin{tabular}{|c|c|c|c|}
\hline Variabel & Koefisien & P-value & Odds Ratio \\
\hline Constant & 3,494 & 0,547 & \\
\hline Usia & 0,10864 & 0,237 & 1,11 \\
\hline Pengalaman & $-0,1182$ & 0,282 & 0,89 \\
\hline Pendidikan & $-1,1033$ & $0,049 * *$ & 0,33 \\
\hline Jumlah Anggota Keluarga & $-1,2083$ & $0,038^{* *}$ & 0,30 \\
\hline Jarak Gudang ke Jalan Raya & $-0,000790$ & 0,607 & 1,00 \\
\hline Biaya Pinjaman & $-0,010078$ & $0,020^{* *}$ & 0,99 \\
\hline Proporsi Garam KP 1 & 0,0546 & 0,681 & 1,06 \\
\hline \multicolumn{4}{|l|}{ Log-Likelihood $=-30,130$} \\
\hline \multicolumn{4}{|c|}{ Test that all slopes are zero: $\mathrm{G}=14,991, \mathrm{DF}=7, P-$ Value $=0,036^{* *}$} \\
\hline \multicolumn{4}{|l|}{ Goodness-of-Fit Tests } \\
\hline Method & Chi-Square & DF & P-value \\
\hline Pearson & 76,343 & 85 & 0,738 \\
\hline Deviance & 60,260 & 85 & 0,981 \\
\hline Hosmer-Lemeshow & 5,597 & 8 & 0,692 \\
\hline $\begin{array}{l}\text { Measures of Association: } \\
\text { Concordant }\end{array}$ & $80,4 \%$ & & \\
\hline
\end{tabular}

Sumber : Data Primer (diolah), 2016

Keterangan : ${ }^{*}=$ nyata pada taraf $a=5 \%$ 


\section{MEASURES OF ASSISOCIATION}

Nilai Measures of Association digunakan untuk melihat keragaman peubah. Berdasarkan nilai Concordant sebesar 80,4 persen dapat diartikan bahwa keragaman variabel dependen dapat dijelaskan oleh variabel independen dalam model tersebut sebesar 80,4 persen, sedangkan sebesar 19,6 persen dijelaskan oleh variabel independen di luar model. Nilai Somers' D dan GoodmanKruskal Gamma yang nilainya mendekati 1 menandakan bahwa daya prediksi model yang diperoleh cukup baik (Firdaus et al. 2011).

\section{UJI PARSIAL DAN PEMBENTUKAN MODEL (UJI WALD)}

Berdasarkan hasil output Program Minitab 11 dalam Tabel 4 menunjukkan bahwa terdapat tiga variabel independen yang berpengaruh nyata terhadap variabel dependen. $\mathrm{H}_{0}=$ variabel independen ke-i tidak berpengaruh nyata terhadap variabel dependen. $\mathrm{H}_{1}=$ variabel independen ke-i berpengaruh nyata terhadap variabel dependen. Nilai P-Value dari ketiga variabel tersebut bernilai lebih kecil dari taraf nyata lima persen $(P$-Value $<0,05)$ dapat disimpulkan bahwa tolak $\mathrm{H}_{0}$ artinya tiga variabel independen tersebut berpengaruh nyata terhadap keputusan petani penggarap untuk berpartisipasi pada suatu pola bagi hasil.

\section{INTERPRETASI NILAI ODDS RATIO}

Berdasarkan Uji Wald diketahui bahwa variabel independen yang berpengaruh nyata terhadap variabel dependen adalah tingkat pendidikan terakhir petani penggarap, jumlah anggota keluarga petani penggarap, dan biaya pinjaman yang dibayar oleh petani penggarap. Selanjutnya, nilai odds ratio dari tiga variabel tersebut dianalisis untuk mengetahui pengaruh ketiga variabel terhadap keputusan petani penggarap untuk berpartisipasi dalam suatu pola bagi hasil tertentu.

\section{Pendidikan}

Nilai P-Value yang diperoleh 0,049 yang lebih kecil dari taraf nyata lima persen $(P$ Value $<0,05)$ sehingga signifikan pada taraf kepercayaan 95 persen dan disimpulkan tolak $\mathrm{H}_{0}$. Artinya, tingkat pendidikan petani penggarap memberikan pengaruh yang nyata terhadap keputusan yang akan diambil dalam berpartisipasi pada suatu pola bagi hasil. Variabel tingkat pendidikan memiliki nilai odds ratio sebesar 0,33 yang artinya semakin tinggi tingkat pendidikan seorang petani penggarap akan meningkatkan peluang pengambilan keputusan untuk berpartisipasi pada pola bagi tiga sebesar 0,33 kali. Kesimpulan ini sesuai dengan apa yang dikemukakan oleh Lole (1995) dan Oriakhi et al. (2012).

Hal ini sesuai dengan temuan di lapang yang menyatakan bahwa petani penggarap responden yang memiliki pendidikan lebih tinggi cenderung untuk berpartisipasi pada pola bagi tiga. Pola bagi tiga lebih menguntungkan daripada pola bagi dua yang harus menanggung biaya tambahan perbaikan lahan dan harus bekerja lebih ekstra karena lahan garam yang digarap bersifat mudah bocor.

\section{Jumlah Anggota Keluarga}

Nilai $P$-Value yang diperoleh 0,038 yang lebih kecil dari taraf nyata lima persen $(P$ Value<0,05) sehingga signifikan pada taraf kepercayaan 95 persen dan disimpulkan tolak $\mathrm{H}_{0}$. Jumlah anggota keluarga petani penggarap berpengaruh nyata terhadap keputusan yang akan diambil dalam berpartisipasi pada suatu pola bagi hasil. Variabel jumlah anggota keluarga petani penggarap memiliki nilai odds ratio sebesar 0,30 yang artinya tambahan seorang anggota keluarga petani penggarap akan meningkatkan peluang pengambilan keputusan untuk berpartisipasi pada pola bagi tiga sebesar 0,30 kali. Hasil penelitian ini telah sesuai dengan temuan Fukunaga et al. (2009) dan Oriakhi et al. (2012). 
Persentase responden pola bagi tiga yang jumlah anggotanya $\geq 2$ orang lebih tinggi nilainya daripada persentase responden pola bagi dua $(76,25$ persen $>69,2$ persen). Ini mengindikasikan bahwa responden yang memiliki jumlah anggota keluarga lebih banyak cenderung akan berpartisispasi pada pola bagi tiga karena lbih menguntungkan. Pola bagi tiga tidak harus menanggung biaya tambahan perbaikan lahan seperti pola bagi dua.

\section{Biaya Pinjaman}

Nilai $P$-Value yang diperoleh 0,020 yang lebih kecil dari taraf nyata lima persen $(P$ Value $<0,05)$ sehingga signifikan pada taraf kepercayaan 95 persen dan disimpulkan tolak $\mathrm{H}_{0}$. Variabel biaya pinjaman yang harus dibayar oleh petani penggarap berpengaruh nyata terhadap keputusan yang akan diambil dalam berpartisipasi pada suatu pola bagi hasil. Variabel jumlah anggota kebiaya pinjaman yang dibayar petani penggarap memiliki nilai odds ratio sebesar 0,99 yang artinya tambahan biaya pinjaman sebesar satu persen akan meningkatkan peluang pengambilan keputusan untuk berpartisipasi pada pola bagi tiga sebesar 0,99 kali.

Range biaya pinjaman yang dibayar oleh petani penggarap pola bagi dua $(56 \%$ $433,33 \%$ ) lebih sempit daripada biaya pinjaman yang dibayar oleh petani penggarap pola bagi tiga (30\% - 467,27\%). Biaya pinjaman yang dibayar oleh petani penggarap pola tiga bahkan mencapai angka 467,27 persen sedangkan untuk pola bagi dua maksimal biaya pinjaman yang dibayarkan mencapai angka 433,33 persen. Hal ini telah sesuai dengan teori. Biaya pinjaman yang tinggi menggambarkan tanggungan pinjaman yang lebih besar. Oleh karena itu, petani penggarap akan memilih untuk berpartisipasi pada pola bagi tiga, dimana tidak memberikan beban biaya yang lebih besar seperti pola bagi dua yang harus menanggung biaya tambahan perbaikan lahan.

\section{SIMPULAN DAN SARAN}

\section{SIMPULAN}

Simpulan dalam penelitian ini adalah sebagai berikut:

1. Pola bagi hasil, baik pola bagi dua maupun pola bagi tiga, ternyata belum memberikan keadilan kepada petani penggarap. Hasil Uji Beda rata-rata keuntungan yang diterima oleh petani penggarap dan pemilik lahan dinyatakan berbeda secara signifikan dengan taraf kepercayaan 95 persen. Ini merupakan salah satu indikator terjadinya ketidakadilan dalam pola bagi hasil usaha garam rakyat di Kabupaten Pamekasan.

2. Nilai rata-rata koefisien perbandingan keuntungan relatif $(\mu)$ untuk pola bagi dua dan pola bagi tiga mendekati nilai 0 . Artinya, terbukti bahwa dua pola bagi hasil tersebut belum memberikan keadilan kepada petani penggarap.

3. Keputusan petani penggarap untuk berpartisipasi terhadap suatu pola bagi hasil dipengaruhi secara signifikan oleh pendidikan terakhir petani penggarap, jumlah anggota keluarga petani penggarap, dan biaya pinjaman yang harus dibayar. Simpulan ini dinyatakan berpengaruh nyata dalam selang kepercayaan 95 persen.

\section{SARAN}

Berdasarkan hasil dan pembahasan dalam penelitian, maka dapat disarankan:

1. Pembentukan koperasi usaha garam rakyat dapat memberikan solusi atas permasalahan pembiayaan dan pemasaran usaha garam rakyat di Kabupaten Pamekasan. Adanya jaminan pengawasan dan kepastian harga dapat mengurangi dominasi pihak-pihak tertentu.

2. Perlu kerjasama dengan pihak-pihak yang memiliki kepentingan dalam usaha garam, misalnya pemilik lahan, tengkulak, perusahaan garam, petani penggarap, dan pemerintah agar dominasi pihak tertentu dapat berkurang dalam usaha garam di 
Kabupaten Pamekasan, terlebih dalam masalah pemasaran dan pembiayaan.

3. Berperan aktif dalam Kelompok Usaha Garam Rakyat (KUGAR) merupakan cara nyata untuk memperoleh pengetahuan mengenai cara produksi garam yang baik, informasi mengenai harga garam, sehingga petani penggarap dapat meningkatkan produksi garam dan pendapatan dari usaha garam yang dijalankan.

\section{DAFTAR PUSTAKA}

Basu S. 1997. Why Institutional Credit Agencies Are Reluctant to Lend to The Rural Poor: A Theoritical Analysis of The Indian Rural Credit Market. World Development Journal. 25(2): 267-280.

[BPS] Badan Pusat Statistik. 2014. Distribusi Perdagangan Komoditi Garam Indonesia 2014 (terhubung berkala). http://www.bps.go.id. Diakses 10 Februari 2016.

Debertin DL. 1986. Agricuktural Production Economics. New York (US): Macmillan Publishing Company.

Firdaus M, Harmini, Farid MA. 2011. Aplikasi Metode Kuantitatif : untuk Manajemen dan Bisnis. Bogor (ID): Institut Pertanian Bogor Press.

Fukunaga K, Huffman WE. 2009. The Role Of Risk and Transaction Costs in Contract Design: Evidence From Farmland Lease Contracts in U.S. Agriculture. American Journal of Agricultural Economics. 91(1): 237-249.

Gujarati DN. 2003. Basic Econometrics : International Edition. New York (US): McGraw Hill.

Jamil AS. 2014. Analisis Sistem Tataniaga Garam Rakyat (Studi Kasus: Desa Lembung Kecamatan Galis Kabupaten Pamekasan Jawa Timur) [Skirpsi]. Bogor (ID): Institut Pertanian Bogor.

[KKP] Kementerian Kelautan dan Perikanan. 2010. Program Swasembada Garam Nasional. Dirjen KP3K Kementerian Kelautan RI. Jakarta.
[KKP] Kementerian Kelautan dan Perikanan. 2014. Volume Produksi Garam (terhubung berkala). http://www.perikananbudidaya.kkp.go.id. Diakses 27 April 2014.

[Kemendag] Kementerian Perdagangan. 2012. Materi Presentasi Rakornas Garam Nasional. Semarang (ID): Kemendag.

Lole UR. 1995. Kajian Ekonomi Sistem Bagi Hasil pada Pola Gaduhan Penggemukan Sapi Potong di Kawasan Timor Barat [Tesis]. Bogor (ID): Institut Pertanian Bogor.

Marshall A. 1920. The Principle of Economics: 8th ed. London (UK): Macmillan and Co.

Negara A. 2013. Pelaksanaan Bagi Hasil Pertanian Sawah di Desa Bumen, Kecamatan Sumowono, Kabupaten Semarang [Skripsi]. Semarang (ID): Universitas Negeri Semarang.

Nurdiani N. 2013. Pola Kemitraan Usaha Garam Rakyat (Studi Kasus: Kabupaten Sumenep, Madura, Jawa Timur) [Tesis]. Bogor (ID): Institut Pertanian Bogor.

Oriakhi HO, Onemolease EA. 2012. Determinants of Rural Household's Willingness to Participate in Community Based Health Insurance Scheme in Edo State, Nigeria. Ethno Medecine Journal. 6(2): 95-102.

Prihantini CI. 2015. Efisiensi Pemasaran Garam Rakyat di Desa Padelegan, Kecamatan Pademawu, Kabupaten Pamekasan, Madura, Jawa Timur [Skripsi]. Bogor (ID): Institut Pertanian Bogor.

Ray T. 1999. Share Tenancy as Strategic Delegation. Journal of Development Economics. 58: 45-60.

Roy J, Serfes K. 2001. Intertemporal Discounting and Tenurial Contracts. Journal of Development Economics. 64: 417-436.

[SEKDAKAB] Sekretariat Daerah Kabupaten Pamekasan. 2015. Pemetaan Potensi Garam Kabupaten Pamekasan. Pamekasan (ID): Sekdakab Pamekasan. 
Scheltema AMPA. 1985. Bagi Hasil di Hindia Belanda. Jakarta (ID): Yayasan Obor Indonesia.

Sukesi. 2011. Analisis Perilaku Masyarakat Petani Garam Terhadap Hasil Usaha di Kota Pasuruan. Pasuruan (ID): Jurnal Mitra Ekonomi dan Manajemen Bisnis. 2(2): $225-244$. 


\section{Lampiran 1. Hasil Uji Beda Rata-rata (Two Sample T-Test and Confidence Interval)}

\section{Two Sample T-Test and Confidence Interval \\ Two sample T for PETANI PENGGARAP vs PEMILIK LAHAN \\ N Mean StDev SE Mean \\ $\begin{array}{llllr}\text { PETANI P } & 93 & 13117155 & 7223007 & 748991\end{array}$ \\ PEMILIK $\quad 93 \quad 658049219 \quad 415253620 \quad 43059794$}

95\% CI for mu PETANI P - mu PEMILIK: ( -729899329, -559964798)

T-Test mu PETANI P = mu PEMILIK (vs not =): T= -14.98 P=0.0000a DF=184

Both use Pooled StDev $=293673067$

\section{Two Sample T-Test and Confidence Interval}

Two sample T for PETANI PENGGARAP POLA 2 vs PEMILIK LAHAN POLA 2

$\begin{array}{lrrrr} & \text { N } & \text { Mean } & \text { StDev } & \text { SE Mean } \\ \text { PETANI P } & 13 & 12833733 & 3746217 & 1039014 \\ \text { PEMILIK } & 13 & 480804887 & 180432095 & 50042859\end{array}$

95\% CI for mu PETANI P - mu PEMILIK: ( -571276799, -364665508)

T-Test mu PETANI P = mu PEMILIK (vs not =): T= -9.35 P=0.0000a DF=24

Both use Pooled StDev $=127612255$

\section{Two Sample T-Test and Confidence Interval}

Two sample T for PETANI PENGGARAP POLA 3 vs PEMILIK LAHAN POLA 3

$\begin{array}{lrrrr} & \text { N } & \text { Mean } & \text { StDev } & \text { SE Mean } \\ \text { PETANI P } & 80 & 13163211 & 7655713 & 855935 \\ \text { PEMILIK } & 80 & 686851422 & 435724856 & 48715520\end{array}$

95\% CI for mu PETANI P - mu PEMILIK: ( -769920699, -577455723)

T-Test mu PETANI P = mu PEMILIK (vs not =): T= -13.83 P=0.0000a DF=158

Both use Pooled StDev $=308151554$

Sumber : Data Diolah dengan Minitab 11 (2016)

Keterangan : $\mathrm{a}=$ nyata pada $\mathrm{a}=5 \%$ 


\section{Lampiran 2. Hasil Analisis Regresi Logistik Faktor-Faktor yang Memengaruhi Keputusan Petani Penggarap Terhadap Pola Bagi Hasil}

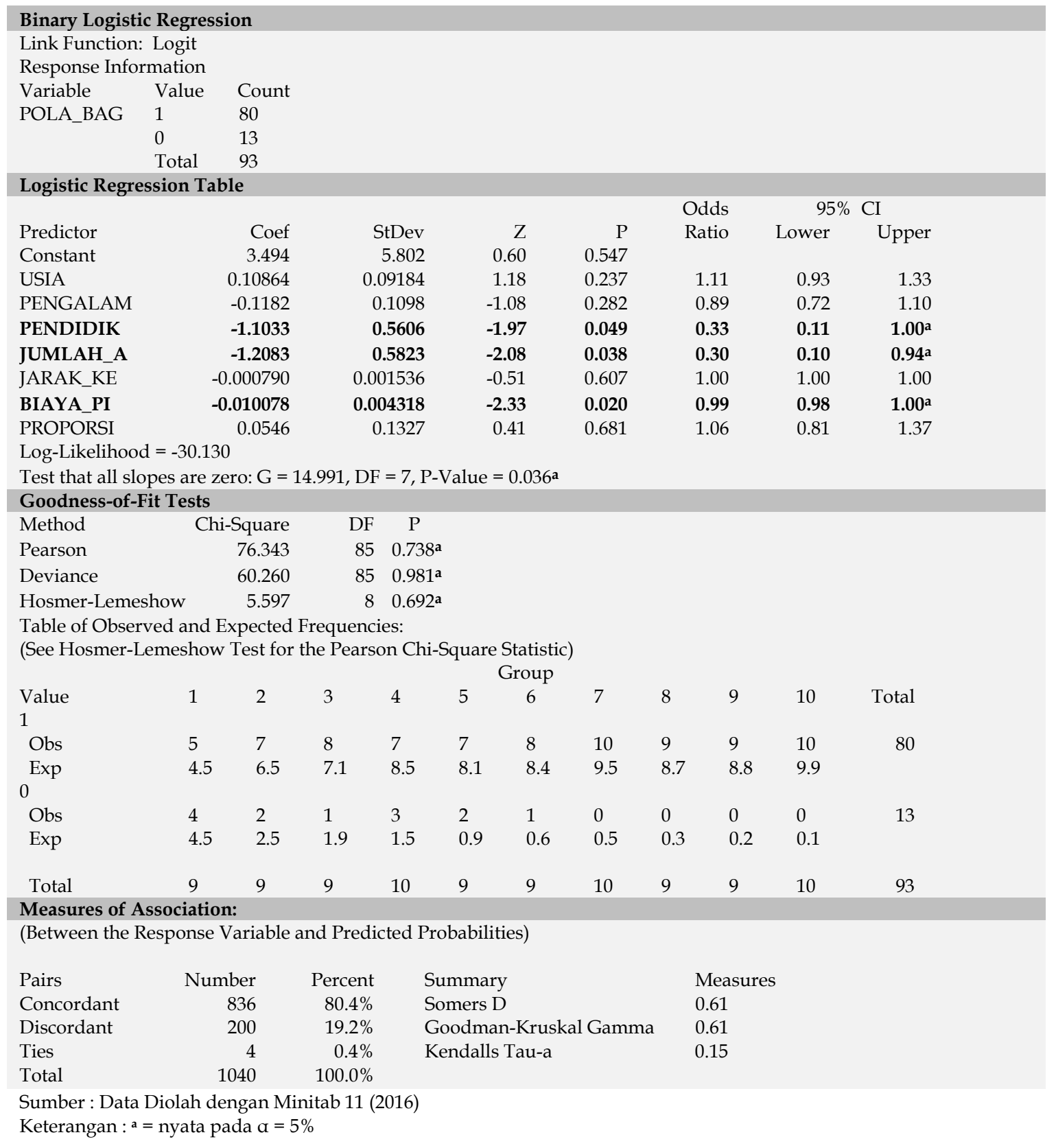


